\title{
Characterization of high-resolution aerosol mass spectra of primary organic aerosol emissions from Chinese cooking and biomass burning
}

\author{
L.-Y. He ${ }^{1}$, Y. Lin ${ }^{1}$, X.-F. Huang ${ }^{1}$, S. Guo ${ }^{2}$, L. Xue ${ }^{1}$, Q. Su ${ }^{1}$, M. Hu ${ }^{2}$, S.-J. Luan ${ }^{1}$, and Y.-H. Zhang ${ }^{2}$ \\ ${ }^{1}$ Key Laboratory for Urban Habitat Environmental Science and Technology, School of Environment and Energy, \\ Peking University Shenzhen Graduate School, Shenzhen, China \\ ${ }^{2}$ State Key Joint Laboratory of Environmental Simulation and Pollution Control, College of Environmental Sciences and \\ Engineering, Peking University, Beijing, China
}

Received: 19 August 2010 - Published in Atmos. Chem. Phys. Discuss.: 7 September 2010

Revised: 23 November 2010 - Accepted: 2 December 2010 - Published: 6 December 2010

\begin{abstract}
Aerosol mass spectrometry has proved to be a powerful tool to measure submicron particulate composition with high time resolution. Factor analysis of mass spectra (MS) collected worldwide by aerosol mass spectrometer (AMS) demonstrates that submicron organic aerosol (OA) is usually composed of several major components, such as oxygenated (OOA), hydrocarbon-like (HOA), biomass burning (BBOA), and other primary OA. In order to help interpretation of component MS from factor analysis of ambient OA datasets, AMS measurements of different primary sources is required for comparison. Such work, however, has been very scarce in the literature, especially for high resolution MS (HR-MS) measurements, which performs improved characterization by separating the ions of different elemental composition at each $\mathrm{m} / \mathrm{z}$ in comparison with unit mass resolution MS (UMR-MS) measurements. In this study, primary emissions from four types of Chinese cooking (CC) and six types of biomass burning (BB) were simulated systematically and measured using an Aerodyne High-Resolution Time-of-Flight AMS (HR-ToF-AMS). The MS of the CC emissions show high similarity, with $\mathrm{m} / \mathrm{z}, 41$ and $\mathrm{m} / \mathrm{z}, 55$ being the highest signals; the MS of the BB emissions also show high similarity, with $\mathrm{m} / \mathrm{z} 29$ and $\mathrm{m} / \mathrm{z} 43$ being the highest signals. The MS difference between the $\mathrm{CC}$ and $\mathrm{BB}$ emissions is much bigger than that between different $\mathrm{CC}$ (or $\mathrm{BB}$ ) types, especially for the HR-MS. The $\mathrm{O} / \mathrm{C}$ ratio of $\mathrm{OA}$ ranges from 0.08 to 0.13 for the $\mathrm{CC}$ emissions and from 0.18 to 0.26 for the BB emissions. The UMR ions of $\mathrm{m} / \mathrm{z} 43, \mathrm{~m} / \mathrm{z} 44, \mathrm{~m} / \mathrm{z}$ 57 , and $\mathrm{m} / z 60$, usually used as tracers in AMS measure-
\end{abstract}

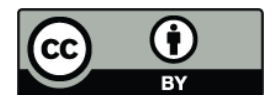

Correspondence to: X.-F. Huang (huangxf@pku.edu.cn) ments, were examined for their HR-MS characteristics in the $\mathrm{CC}$ and $\mathrm{BB}$ emissions. In addition, the MS of the $\mathrm{CC}$ and $\mathrm{BB}$ emissions are also compared with component MS from factor analysis of ambient OA datasets observed in China, as well as with other AMS measurements of primary sources in the literature. The MS signatures of cooking and biomass burning emissions revealed in this study can be used as important reference for factor analysis of ambient OA datasets, especially for the relevant studies in East Asia.

\section{Introduction}

Organic aerosol (OA) is a major type of atmospheric submicron aerosols and comes from various natural and anthropogenic sources, including both primary organic aerosol (POA) emitted directly as particles, and secondary organic aerosol (SOA) photochemically formed from volatile organic compounds (VOCs) in the atmosphere (Zhang et al., 2007; Kroll and Seinfeld, 2008; Jimenez et al., 2009). Due to the high complexity of OA composition, only $\sim 10 \%$ of its mass has been identified as specific compounds (Rogge et al., 1993; Simoneit et al., 2004). Up to now, the primary sources and secondary formation mechanisms of OA are still quite uncertain.

In recent years, some research efforts have been focusing on classifying OA by category rather than identifying specific compounds and the technique of aerosol mass spectrometry has proved to be a promising one. The Aerosol Mass Spectrometer (AMS) manufactured by Aerodyne Inc. (Billerica, USA) can determine chemical composition of submicron aerosol on-line with high time resolution based on thermal vaporization and electron ionization (EI). Factor analysis

Published by Copernicus Publications on behalf of the European Geosciences Union. 
of the mass spectra (MS) collected worldwide by AMS demonstrates that $\mathrm{OA}$ is usually composed of several major components, such as oxygenated (OOA), hydrocarbon-like (HOA), biomass burning (BBOA), and other primary organic aerosols (Lanz et al., 2007; Zhang et al., 2007; Jimenez et al., 2009; $\mathrm{Ng}$ et al., 2010). The OOA has been revealed to be a good surrogate of SOA, and the HOA can be mostly attributed to combustion sources like vehicle exhaust.

Another significant primary OA source is cooking emissions. Some previous studies reported that meat cooking emissions contributed $\sim 20 \%$ to particulate organic matter in $\mathrm{PM}_{2.5}$ in Los Angeles, Hong Kong, and Beijing (Schauer et al., 1996; Schauer and Cass, 2000; Zheng et al., 2006; Wang et al., 2009). Therefore, cooking emissions can play an important role in determining ambient OA loadings. Recently, cooking-related organic aerosol (COA) has also been identified to be significant by factor analysis of AMS datasets of urban atmospheres (Allan et al., 2010; Huang et al., 2010). Since the characteristics of cooking emissions strongly dependent on cooking methods and ingredients, the OA features in Chinese cooking emissions could be different from western-style cooking due to the unique styles of Chinese cooking (Rogge et al., 1991; He et al., 2004).

In order to understand the MS signatures of different primary OA sources and thus help interpretation of MS component spectra from factor analysis of ambient datasets, direct AMS measurements of OA in different primary emissions is required for comparison. Mohr et al. (2009) recently reported on the AMS measurement results of some typical motor vehicles, meat cooking, and trash burning emissions, and pointed out some of the AMS signatures of these OA sources. Similar work, however, has been very scarce in the literature and thus the MS signatures of different primary OA sources have not been well established and confirmed yet. On the other hand, the characteristics of source emissions may vary geographically. For example, burning of biomass fuel and crop waste is far more popular in rural areas in China than in developed countries. Since scarce sources and conditions were analyzed by AMS before, more experiments will be useful to form the generalities for different primary OA sources.

The purpose of this work is to characterize MS signatures of OA in primary emissions from Chinese cooking and biomass burning using an Aerodyne High-Resolution Timeof-Flight AMS (HR-ToF-AMS) of Peking University Shenzhen Graduate School. Compared to an Aerodyne unit massresolution (UMR) AMS, the HR-ToF-AMS is able to separate the ions of different elemental composition at each integer $\mathrm{m} / \mathrm{z}$ and thus performs improved characterization of OA and allows for a better factor analysis of MS with statistical techniques (DeCarlo et al., 2006; Docherty et al., 2008; Aiken et al., 2009; Huang et al., 2010). The MS measured for Chinese cooking and biomass burning are also used to compare with relevant component MS from factor analysis of ambient OA datasets observed in China, as well as with primary OA measurement results in the literature.

\section{Experimental methods}

\subsection{Description of the combustion simulation system}

The simulation of biomass burning (BB) and Chinese cooking (CC) emissions was performed in the Laboratory of Biomass Burning Simulation at Peking University Shenzhen Graduate School. The burning simulation system in the laboratory, as shown in Fig. S-1, was designed and constructed according to the one described in Zhang et al. (2008). The system consisted of five main parts: a combustion pan, a hood, a dilution tunnel, a residence chamber, and several sampling ports. All the relevant parts of the system were made of stainless steel to minimize potential adsorption effect and artifacts. During a biomass burning event, the biomass sample was placed on the combustion pan and then ignited. A recent study found that significant MS difference of OA emissions may exist between the flaming and smoldering phases of the burning of one wood type (Weimer et al., 2008). Since the biomass samples were burning with good ventilation in this study, the BB emissions measured were more representative of the flaming phase. In order to simulate cooking emissions, the combustion pan was substituted by a hotplate, on which a frying pan was used to cook Chinese dishes. The emitted smoke was collected together with ambient air by the hood above, and then went through the dilution tunnel, where it was diluted with zero air by a controlled ratio (10 times for biomass burning and no dilution for cooking). After dilution, the smoke went into the residence chamber, where it had to reside for $\sim 30 \mathrm{~s}$ to cool down. The temperature in the residence chamber ranged between 25 and $40^{\circ} \mathrm{C}$ during the experiments. The smoke was then sampled through a port and further diluted by zero air (5 times for all). After passing through a $\mathrm{PM}_{2.5}$ cyclone to remove coarse particles, the smoke was finally sampled by the HR-ToF-AMS. The total time for the smoke to transport from the fire to the inlet of the HR-ToF-AMS was $\sim 45 \mathrm{sec}-$ onds. The OA concentrations sampled by the HR-ToF-AMS for all the experiments were less than $100 \mu \mathrm{g} \mathrm{m}^{-3}$, as shown in Fig. S-2, which is atmospherically relevant.

\subsection{Simulation of Chinese cooking and biomass burning emissions}

Cooking emissions of four traditional Chinese dishes were simulated and analyzed in this study, including Hand-Ripped Cabbage (CC\#1), Scrambled Eggs with Tomatoes (CC\#2), Kung Pao Chicken (CC\#3), and Spareribs Braised in Brown Sauce (CC\#4). These dishes were selected to test because they are among most popular Chinese dishes and their cooking processes use various ingredients (e.g., vegetables, eggs, pork, and chicken) and include different cooking methods (e.g., frying, sauteing, stewing, and simmering). The ingredients used to cook these dishes are listed in Table S- 1 . The temperature of the hotplate was set at $160-180^{\circ} \mathrm{C}$ for 
the cooking. Each dish was cooked for 2-3 times for AMS measurements. Burning emissions of six types of biomass were simulated and analyzed, including wood of fir (BB\#1), pine (BB\#2), willow (BB\#3), and wattle (BB\#4), sugarcane leaves (BB\#5), and rice straw (BB\#6). These types of biomass are popular biofuel used for cooking and heating in Chinese rural areas. Rice straw and sugarcane leaves are two major types of agricultural waste in Chinese rural areas and usually burned out intensively on the farmland after harvest, causing severe regional hazy days. The biomass materials used in this study were collected in the rural areas of Guangdong Province and Beijing and had all been air-dried before the experiments. About $0.5-1.5 \mathrm{~kg}$ biomass were used for a single burning event. The burning of each biomass species was repeated for 2-4 times, except only once for pine burning. All the experiments were carried out in December 2009 with a mean ambient temperature of $17^{\circ} \mathrm{C}$.

\subsection{HR-ToF-AMS operation and data processing}

An Aerodyne HR-ToF-AMS was used to measure the submicron particles emitted from the sources. A detailed instrumental description of HR-ToF-AMS can be found in DeCarlo et al. (2006). The HR-ToF-AMS sampled isokinetically at a flow rate of $80 \mathrm{cc} \mathrm{min}^{-1}$. During this study, the HR-ToF-AMS operated in a cycle of two modes, i.e., 1 min $\mathrm{V}$-mode to obtain mass concentrations and $1 \mathrm{~min} \mathrm{~W}$-mode to obtain high-resolution mass spectra. The HR-ToF-AMS was calibrated for inlet flow, ionization efficiency (IE), and particle sizing before and after the source measurements following the standard protocols (Jayne et al., 2000; Jimenez et al., 2003; Drewnick et al., 2005). The calibration of IE was conducted using size-selected pure ammonium nitrate particles, and the calibration of particle size was conducted using mono-disperse polystyrene latex spheres. Standard ToF-AMS data analysis software packages (including SQUIRREL version 1.49 and PIKA version 1.08) downloaded from the ToF-AMS-Resources webpage (http: //cires.colorado.edu/jimenez-group/ToFAMSResources/

ToFSoftware/index.html) were used to generate unit and high-resolution mass spectra from the V-mode and W-mode data, respectively, using the methods outlined in DeCarlo et al. (2006). Elemental analysis (C, H, O, and N) of the HR-MS was carried out with the methods described previously (Aiken et al., 2007, 2008). In the data processing, only the data with OA concentrations elevated largely from the baseline concentrations ( $\sim 10$ times) were used to generate representative HR-MS for different CC and BB emissions, which were calculated based on averages of 8-54 min data. Organic HR-MS were extracted from the dataset to be discussed in the following sections.

\section{Results and discussion}

\subsection{HR-MS profiles of OA from the sources}

Figure 1 gives the average HR-MS of OA observed for the primary emissions of four types of Chinese cooking and six types of biomass burning, which are presented in the form of UMR-MS by stacking the ions of the same mass integer. All the ten MS are dominated by the ion series of $\mathrm{C}_{n} \mathrm{H}_{2 n+1}^{+}$and $\mathrm{C}_{m} \mathrm{H}_{2 m+1} \mathrm{CO}^{+}(m / z, 29,43,57,71,85 \ldots)$ and $\mathrm{C}_{n} \mathrm{H}_{2 n-1}^{+}$and $\mathrm{C}_{m} \mathrm{H}_{2 m-1} \mathrm{CO}^{+}(m / z 41,55,69,83 \ldots)$, indicating large presence of saturated alkanes, alkenes, and also possible longchain fatty acids in the primary $\mathrm{OA}$ from the $\mathrm{CC}$ and $\mathrm{BB}$ emissions. However, the most prominent mass fragments are different between the CC and BB emissions: $\mathrm{m} / \mathrm{z} 41$ and $\mathrm{m} / \mathrm{z}$ 55 are the two most abundant UMR ions for the CC emissions, while $\mathrm{m} / \mathrm{z} 29$ and $\mathrm{m} / \mathrm{z} 43$ are the most abundant UMR ions for the $\mathrm{BB}$ emissions. In addition, there appears to be more mass fragments in the range of $m / z>100$ in the $\mathrm{BB}$ emissions than in the $\mathrm{CC}$ emissions.

The HR-MS of the CC emissions indicate that $\mathrm{m} / \mathrm{z} 41$ and $\mathrm{m} / z, 55$ are dominated by $\mathrm{C}_{3} \mathrm{H}_{5}^{+}$and $\mathrm{C}_{4} \mathrm{H}_{7}^{+}$, respectively, both of which are fragments resulting from EI of unsaturated organic compounds. As unsaturated fatty acids were identified as abundant OA species from Chinese cooking emissions by GC-MS analysis (He et al., 2004; Zhao et al., 2007), the high signal of $\mathrm{m} / \mathrm{z}, 41$ and $\mathrm{m} / \mathrm{z} 55$ is a reasonable result of the AMS measurements. A recent AMS measurement of primary cooking emissions from heating of seed oil by Allan et al. (2010) and a charbroiling reference spectrum shown by Lanz et al. (2007) also gave the highest ion signals at $\mathrm{m} / \mathrm{z}$ 41 and $m / z 55$ in UMR-MS profile. However, the AMS measurement of primary cooking emissions from meat charbroiling by Mohr et al. (2009) shows the highest ion signals at $\mathrm{m} / \mathrm{z}$ 43 and $\mathrm{m} / \mathrm{z} 55$ in the UMR-MS profiles. As frying is a major process for the cooking of most Chinese dishes, the MS signatures of OA generated from frying could be more dominant than those from meat charbroiling in Chinese cooking emissions.

The HR-MS of the BB emissions indicate that the prominent signals at $\mathrm{m} / z, 29$ and $\mathrm{m} / \mathrm{z}, 43$ are mainly due to the large presence of the oxygen-containing ions of $\mathrm{CHO}^{+}$and $\mathrm{C}_{2} \mathrm{H}_{3} \mathrm{O}^{+}$, respectively, which are more abundant than the hydrocarbon ions at the same mass integers. In fact, not only $\mathrm{m} / \mathrm{z} 29$ and $\mathrm{m} / \mathrm{z} 43$ but also most other mass integers contribute to oxygen-containing ions. The high fractions of oxygen-containing ions in the HR-MS of the BB emissions are consistent with previous findings that polar, oxygencontaining, and water-soluble organic compounds dominate primary aerosols emitted from biomass burning (Novakov and Corrigan, 1996; Narukawa et al., 1999). There also exist significant signals at $\mathrm{m} / \mathrm{z}, 44$ and $\mathrm{m} / \mathrm{z} 60$, the two tracer fragments for OOA and BBOA, respectively, which are discussed in Sect. 3.4. These characteristics are generally consistent with the HR-MS of OA from pine burning reported 

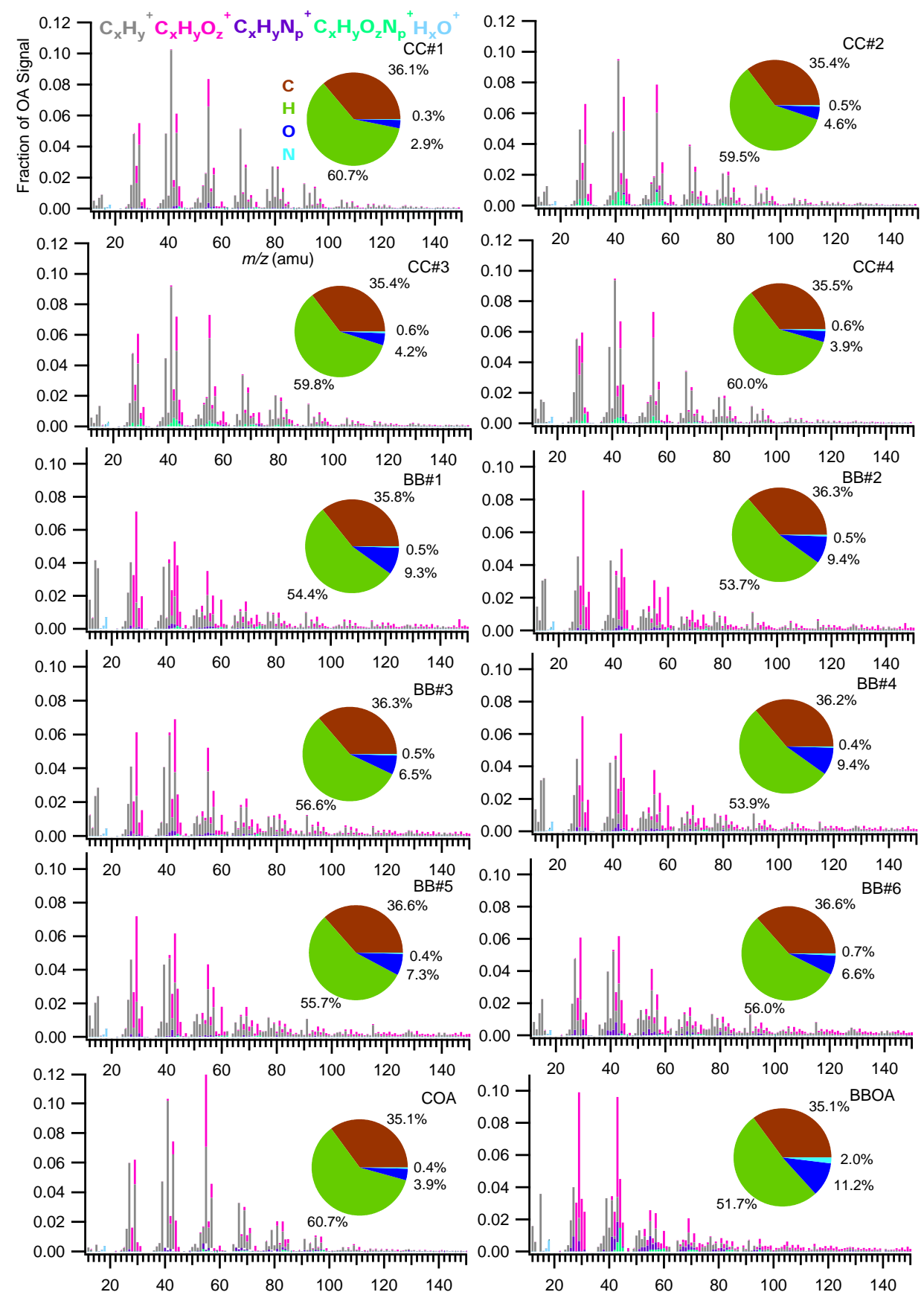

Fig. 1. The HR-MS profiles and elemental composition (pie charts inserted) of OA from ten types of Chinese cooking and biomass burning emissions and two PMF-resolved OA factors based on ambient datasets: Hand-Ripped Cabbage (CC\#1); Scrambled Eggs with Tomatoes (CC\#2); Kung Pao Chicken (CC\#3); Spareribs Braised in Brown Sauce (CC\#4); fir (BB\#1); pine (BB\#2); willow (BB\#3); wattle (BB\#4); sugarcane leaves (BB\#5); rice straw (BB\#6); cooking-related OA in Beijing ambient (COA); biomass burning OA in Shenzhen ambient (BBOA).

by Aiken et al. $(2008,2009)$ and the UMR-MS of OA from wood burning reported by Alfarra et al. (2007) and Weimer et al. (2008). This study consolidates the MS signatures of OA from primary BB emissions by more sample types. The MS signal fractions of $m / z>100$ are $11-13 \%$ for the six BB types, significantly higher than 5-7\% for the four CC types, which implies that OA from primary BB emissions contains high molecular weight organic compounds. This can be supported by previous findings that biomass burning aerosol contains a large amount of humic-like substances (MayolBracero et al., 2002; Gelencser et al., 2000; Lin et al., 2010). 
Table 1. Correlation coefficients $\left(R^{2}\right)$ between UMR-MS (and HR-MS, in grey cells) profiles of different source emissions and PMF factors.

\begin{tabular}{|c|c|c|c|c|c|c|c|c|c|c|c|c|c|}
\hline UMR & CC\#1 & $\mathrm{CC} \# 2$ & $\mathrm{CC} \# 3$ & $\mathrm{CC} \# 4$ & BB\#1 & BB\#2 & BB\#3 & BB\#4 & BB\#5 & BB\#6 & $\mathrm{COA}$ & BBOA & $R^{2}$ \\
\hline CC\#1 & 1.00 & 0.98 & 0.97 & 0.94 & 0.59 & 0.54 & 0.83 & 0.67 & 0.73 & 0.79 & 0.93 & 0.46 & CC\#1 \\
\hline $\mathrm{CC} \# 2$ & 0.96 & 1.00 & 0.99 & 0.97 & 0.70 & 0.66 & 0.91 & 0.78 & 0.83 & 0.88 & 0.94 & 0.59 & $\mathrm{CC} \# 2$ \\
\hline $\mathrm{CC} \# 3$ & 0.97 & 0.98 & 1.00 & 0.97 & 0.70 & 0.66 & 0.92 & 0.79 & 0.84 & 0.89 & 0.93 & 0.61 & $\mathrm{CC \# 3}$ \\
\hline CC\#4 & 0.95 & 0.97 & 0.97 & 1.00 & 0.74 & 0.68 & 0.90 & 0.80 & 0.85 & 0.88 & 0.90 & 0.60 & $\mathrm{CC \# 4}$ \\
\hline BB\#1 & 0.41 & 0.54 & 0.50 & 0.54 & 1.00 & 0.96 & 0.89 & 0.98 & 0.93 & 0.87 & 0.62 & 0.89 & BB\#1 \\
\hline BB\#2 & 0.32 & 0.46 & 0.42 & 0.44 & 0.94 & 1.00 & 0.85 & 0.96 & 0.94 & 0.87 & 0.55 & 0.88 & BB\#2 \\
\hline BB\#3 & 0.75 & 0.85 & 0.84 & 0.83 & 0.84 & 0.75 & 1.00 & 0.94 & 0.96 & 0.97 & 0.84 & 0.80 & BB\#3 \\
\hline BB\#4 & 0.51 & 0.64 & 0.62 & 0.64 & 0.97 & 0.94 & 0.92 & 1.00 & 0.98 & 0.95 & 0.68 & 0.89 & BB\#4 \\
\hline BB\#5 & 0.62 & 0.74 & 0.73 & 0.74 & 0.89 & 0.87 & 0.95 & 0.97 & 1.00 & 0.98 & 0.74 & 0.86 & BB\#5 \\
\hline BB\#6 & 0.70 & 0.81 & 0.81 & 0.80 & 0.81 & 0.78 & 0.95 & 0.91 & 0.96 & 1.00 & 0.79 & 0.81 & BB\#6 \\
\hline $\mathrm{COA}$ & 0.86 & 0.87 & 0.89 & 0.90 & 0.44 & 0.32 & 0.74 & 0.52 & 0.64 & 0.69 & 1.00 & 0.48 & $\mathrm{COA}$ \\
\hline BBOA & 0.18 & 0.31 & 0.28 & 0.29 & 0.82 & 0.84 & 0.59 & 0.78 & 0.69 & 0.61 & 0.20 & 1.00 & $\mathrm{BBOA}$ \\
\hline$R^{2}$ & CC\#1 & $\mathrm{CC} \# 2$ & $\mathrm{CC} \# 3$ & $\mathrm{CC \# 4}$ & BB\#1 & BB\#2 & BB\#3 & BB\#4 & BB\#5 & BB\#6 & $\mathrm{COA}$ & BBOA & HR \\
\hline
\end{tabular}

The HR-MS observed for the primary CC and BB emissions are also used to compare with two component HRMS of the cooking-related organic aerosol (COA) and the biomass burning organic aerosol (BBOA) (as shown in Fig. 1) resolved by positive matrix factorization (PMF) analysis of ambient HR-MS datasets. The COA was identified in OA of urban Beijing in summer 2008 (Huang et al., 2010) and the BBOA was identified in OA of urban Shenzhen in fall 2009 (He et al., 2010). It can be seen in Fig. 1 that the major MS signatures, such as the most prominent ions and fraction of oxygen-containing ions, of the COA and BBOA match those of the $\mathrm{CC}$ and $\mathrm{BB}$ emissions measured in this study, respectively, supporting the representativeness of the $\mathrm{COA}$ and BBOA in the corresponding AMS-PMF studies. The MS of the $\mathrm{CC}$ and $\mathrm{BB}$ emissions measured in this study are significantly different from the MS from vehicle exhaust and plastic burning, which typically have the highest ion signal at $\mathrm{m} / \mathrm{z} 43$ (Mohr et al., 2009), and also highly different from the MS of OOA, which typically have the highest ion signal at $\mathrm{m} / \mathrm{z} 44$ (Zhang et al., 2007; Ng et al., 2010).

\subsection{Similarity of the MS profiles}

As a general evaluation for the similarity of the MS profiles of the different emissions, their MS correlation coefficients $\left(R^{2}\right)$ were calculated and summarized in Table 1 . The variations in correlation coefficient for UMR-MS and HR-MS were found to be well correlated $\left(R^{2}=0.97\right)$. In terms of either UMR-MS or HR-MS, the four types of CC emissions show high inter-correlation $\left(R^{2} \geqq 0.94\right)$ and the six types of $\mathrm{BB}$ emissions also show high inter-correlation $\left(R^{2} \geqq 0.75\right)$, denoting a good consistency of the MS profiles of different types of $\mathrm{CC}$ (or $\mathrm{BB}$ ) emissions. For the MS correlation between a $\mathrm{CC}$ source and a $\mathrm{BB}$ source, $R^{2}$ ranges from 0.54 to 0.92 for UMR-MS, with a mean value of 0.77 , and ranges from 0.32 to 0.85 for HR-MS, with a mean value of 0.63 .
These results have two implications: first, the MS difference between $\mathrm{CC}$ emissions and $\mathrm{BB}$ emissions is much bigger than that between different $\mathrm{CC}$ (or $\mathrm{BB}$ ) types, therefore $\mathrm{OA}$ from $\mathrm{BB}$ and $\mathrm{CC}$ emissions are very likely to be separated into two components in factor analysis of AMS ambient datasets; second, there exists higher difference between $\mathrm{CC}$ emissions and BB emissions in HR-MS than in UMR-MS, which would allow better separation of the two OA components in the factor analysis. In terms of either UMR-MS or HR-MS, the two OA components derived from the ambient datasets, i.e., COA and BBOA, show significantly higher correlation with the $\mathrm{CC}$ and $\mathrm{BB}$ emissions, respectively (in Table 1), well confirming their representativeness.

\subsection{Elemental composition of $\mathrm{OA}$ from the sources}

The elemental composition of the different $\mathrm{CC}$ and BB emissions is presented as inserted plots in Fig. 1. Figure 2 compares their elemental ratios of $\mathrm{H} / \mathrm{C}, \mathrm{O} / \mathrm{C}$, and $\mathrm{N} / \mathrm{C}$, as well as those of the COA and BBOA. Compared to the CC emissions and $\mathrm{COA}$, the $\mathrm{BB}$ emissions and $\mathrm{BBOA}$ have higher $\mathrm{O} / \mathrm{C}$ ratios but lower $\mathrm{H} / \mathrm{C}$ ratios. The $\mathrm{O} / \mathrm{C}$ ratios range from 0.18 to 0.26 for the six types of $\mathrm{BB}$ emissions and from 0.08 to 0.13 for the four types of $\mathrm{CC}$ emissions. Also based on HR-ToF-AMS measurements, Mohr et al. (2009) reported $\mathrm{O} / \mathrm{C}$ ratios of 0.11 and 0.14 for cooking of fatty hamburger and chicken without skin, respectively; Aiken et al. (2008) reported $\mathrm{O} / \mathrm{C}$ ratios of 0.31 and 0.42 for lodgepole pine and sage/rabbitbrush burning, respectively. Compared to the results in the literature, our measurements observed similar $\mathrm{O} / \mathrm{C}$ ratio levels for $\mathrm{CC}$ and $\mathrm{BB}$ emissions, but with broader ranges due to more sample types tested. It should also be noted that a recent study has shown that different burning conditions may also strongly influence the ratios of $\mathrm{m} / \mathrm{z} 44$ to total organics (44/org, a surrogate of $\mathrm{O} / \mathrm{C}$ ratio in quadrupole AMS measurement) from wood burning 


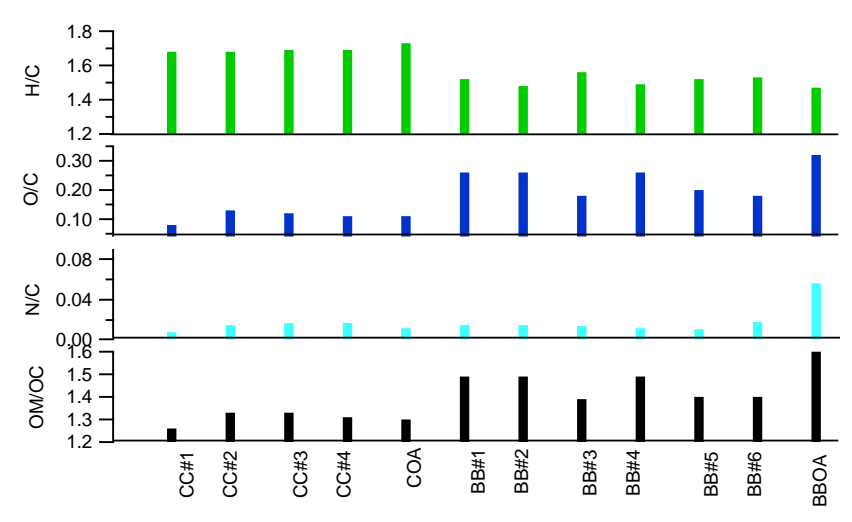

Fig. 2. Comparison of $\mathrm{H} / \mathrm{C}, \mathrm{O} / \mathrm{C}, \mathrm{N} / \mathrm{C}$, and $\mathrm{OM} / \mathrm{OC}$ ratios of $\mathrm{OA}$ from ten types of Chinese cooking and biomass burning emissions and two PMF-resolved OA factors.

emissions (Weimer et al., 2008). Combining the findings in this study and in the literature, it is safe to say that OA from biomass burning emissions would have significantly higher $\mathrm{O} / \mathrm{C}$ ratio levels than $\mathrm{OA}$ from cooking emissions. All the $\mathrm{CC}$ and $\mathrm{BB}$ emissions measured in this study have $\mathrm{O} / \mathrm{C}$ ratios lower than those of OOA (0.5-1) (Jimenez et al., 2009), consistent with their nature of primary origin.

Compared to the HR-ToF-AMS measurements of vehicle exhaust and plastic burning $(\mathrm{O} / \mathrm{C}$ ratios $=0.03-0.04)$ reported by Mohr et al. (2009), the CC and BB emissions measured in this study obviously have higher $\mathrm{O} / \mathrm{C}$ ratios. When compared to the diesel car exhaust $(\mathrm{O} / \mathrm{C}$ ratios $=0.097-0.19)$ measured by Chirico et al. (2010), however, the CC emissions measured in this study have similar $\mathrm{O} / \mathrm{C}$ ratio levels. Chirico et al. (2010) also showed that the O/C ratios of diesel car exhaust can vary significantly depending on the engines and aftertreatment technology. In addition, HOA was resolved with $\mathrm{O} / \mathrm{C}$ ratios of $0.06-0.17$ in previous $\mathrm{OA}$ factor analysis of ambient datasets (Aiken et al., 2008, 2009; Huang et al., 2010), which are also similar to those of the CC emissions. Therefore, it is seen that the $\mathrm{O} / \mathrm{C}$ ratios of vehicle exhaust and $\mathrm{CC}$ emissions overlap somewhat, which may be an unfavourable factor for complete separation of COA and HOA in factor analysis of ambient datasets. It is worthy noting that two very recent chamber studies indicated that primary OA from diesel car exhaust can increase its $\mathrm{O} / \mathrm{C}$ ratio quickly with aging by photo-oxidation (Miracolo et al., 2010; Chirico et al., 2010), which could lead to higher $\mathrm{O} / \mathrm{C}$ ratios of HOA observed in filed campaigns than those by direct exhaust measurements.

The N/C ratios are small (0.008-0.018) for all the CC and BB emissions. The BBOA identified in Shenzhen, however, has a uniquely high $\mathrm{N} / \mathrm{C}$ ratio of 0.06 , implying that unknown high $\mathrm{N}$-containing emissions might be included in the BBOA. Due to the small factions of nitrogen in the OA, the variation of $\mathrm{OM} / \mathrm{OC}$ (organic matter mass to organic carbon mass) ratio among different source types resembles that of

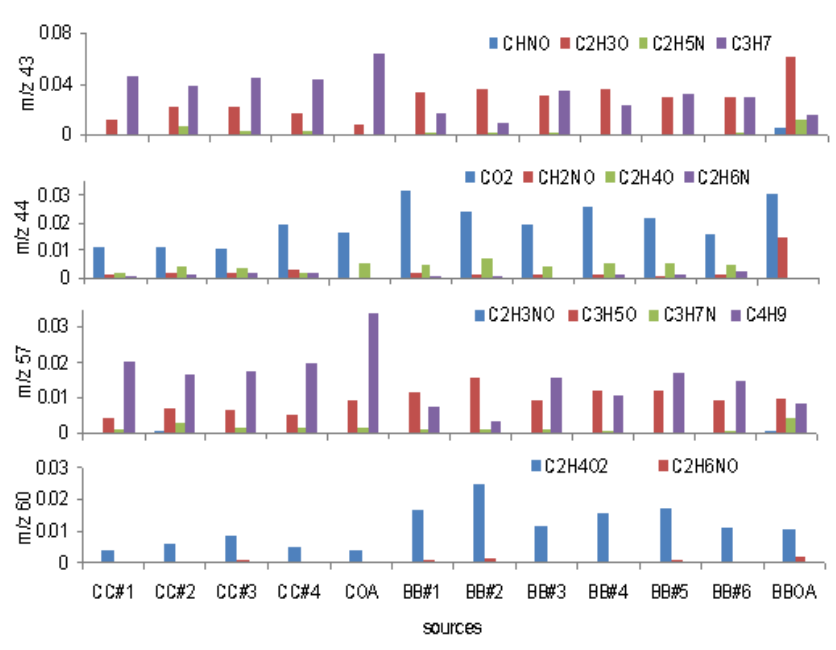

Fig. 3. Comparison of HR-MS ion signals at $\mathrm{m} / \mathrm{z} 43, \mathrm{~m} / \mathrm{z} 44$, $\mathrm{m} / \mathrm{z} 57$, and $\mathrm{m} / \mathrm{z} 60$ of OA from ten types of Chinese cooking and biomass burning emissions and two PMF-resolved OA factors.

$\mathrm{O} / \mathrm{C}$ ratio, ranging from 1.26 to 1.33 for the four types of $\mathrm{CC}$ emissions and from 1.39-1.49 for the six types of BB emissions.

\subsection{Characteristics of tracer ions in MS}

The UMR ions of $\mathrm{m} / \mathrm{z} 43, \mathrm{~m} / \mathrm{z} 44, \mathrm{~m} / \mathrm{z} 57$, and $\mathrm{m} / \mathrm{z} 60$ have been usually used as tracers in MS of total OA, OOA, $\mathrm{HOA}$, and BBOA, respectively, because they typically correlate well with these OA components in statistical analysis of ambient datasets (Zhang et al., 2005; Alfarra et al., 2007; $\mathrm{Ng}$ et al., 2010). Therefore, it is necessary and interesting to examine the patterns of these ions in the $\mathrm{CC}$ and $\mathrm{BB}$ emissions measured in this study to explore their representativeness and possible interferences in the case of cooking and biomass burning OA.

Taking advantage of the HR-MS in this study, it is possible to first examine what ions comprise these four UMR ions. Fig. 3 compares the composition of mass fragments at $\mathrm{m} / \mathrm{z} 43, \mathrm{~m} / \mathrm{z} 44, \mathrm{~m} / \mathrm{z} 57$, and $\mathrm{m} / \mathrm{z} 60$ for the BB and CC emissions, as well as those of the COA and BBOA. For $\mathrm{m} / \mathrm{z}$ $43, \mathrm{C}_{2} \mathrm{H}_{3} \mathrm{O}^{+}$and $\mathrm{C}_{3} \mathrm{H}_{7}^{+}$are always the two major ions at this mass integer. However, the signal abundance of $\mathrm{C}_{3} \mathrm{H}_{7}^{+}$in the $\mathrm{CC}$ emissions is much higher than that of $\mathrm{C}_{2} \mathrm{H}_{3} \mathrm{O}^{+}$, while in the $\mathrm{BB}$ emissions the signal abundance of $\mathrm{C}_{3} \mathrm{H}_{7}^{+}$is similar to or even lower than that of $\mathrm{C}_{2} \mathrm{H}_{3} \mathrm{O}^{+}$. For $m / z 44, \mathrm{CO}_{2}^{+}$is always the dominant ion, denoting high accordance of $\mathrm{m} / \mathrm{z}$ 44 and $\mathrm{CO}_{2}^{+}$. The UMR ion of $m / z 57$ has been regarded as a good reference for HOA emitted from primary combustion sources, which seems to be the case for the $\mathrm{CC}$ emissions but questionable for the $\mathrm{BB}$ emissions. The signal abundance of $\mathrm{C}_{4} \mathrm{H}_{9}^{+}$in the $\mathrm{CC}$ emissions is much higher than that of $\mathrm{C}_{3} \mathrm{H}_{5} \mathrm{O}^{+}$, while in the $\mathrm{BB}$ emissions the signal abundance of $\mathrm{C}_{4} \mathrm{H}_{9}^{+}$is similar to or even lower than that of $\mathrm{C}_{3} \mathrm{H}_{5} \mathrm{O}^{+}$. 


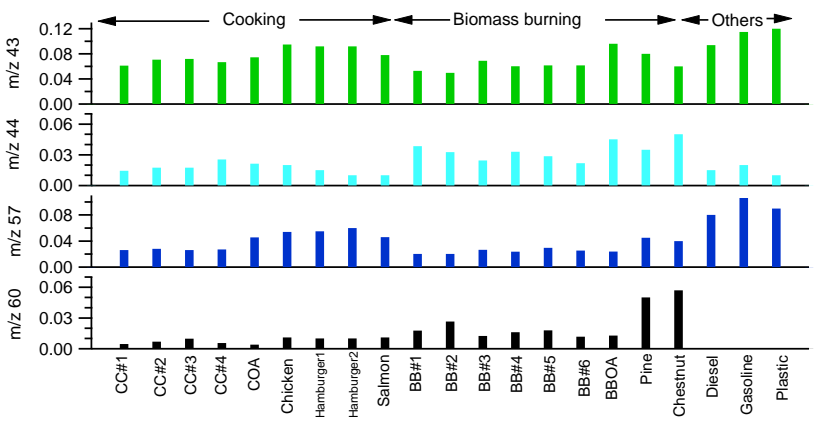

Fig. 4. Comparison of UMR-MS ion signals at $\mathrm{m} / \mathrm{z} 43, \mathrm{~m} / \mathrm{z} 44$, $\mathrm{m} / \mathrm{z}, 57$, and $\mathrm{m} / \mathrm{z}, 60$ of OA from ten types of Chinese cooking and biomass burning emissions and two PMF-resolved OA factors, as well as those from other primary sources as reported in the literature (data source: chicken w/o skin, lean hamburger (\#1), fatty hamburger (\#2), salmon, diesel and gasoline engines, and plastic burning from Mohr et al., 2009; pine burning from Aiken et al., 2009; chestnut burning from Alfarra et al., 2007).

Aiken et al. (2009) reported a HR-MS of pine burning, in which $\mathrm{C}_{3} \mathrm{H}_{5} \mathrm{O}^{+}$is also higher than $\mathrm{C}_{4} \mathrm{H}_{9}^{+}$. This result suggests that $\mathrm{m} / z 57$ in UMR-MS may not be a good tracer for hydrocarbons in biomass burning emissions. For $m / z$ 60, it is always dominated by $\mathrm{C}_{2} \mathrm{H}_{4} \mathrm{O}_{2}^{+}$, supporting the use of this UMR ion as tracer.

Figure 4 compares the signal abundances of $\mathrm{m} / \mathrm{z}, 43, \mathrm{~m} / \mathrm{z}$ $44, m / z 57$, and $m / z 60$ in UMR-MS of OA from different primary sources observed in this study and reported in the literature, in order to extract general characteristics of these ions in cooking and biomass burning emissions. The signal abundances of $\mathrm{m} / \mathrm{z}, 43$ are similar for cooking and biomass burning emissions, in the range of $0.05-0.10$, but they are slightly lower than those from vehicle exhaust and plastic burning. The signal abundances of $m / z 44$ generally show higher values for biomass burning emissions (0.02-0.05) than those from cooking emissions $(\leq 0.02)$, vehicle exhaust, and plastic burning. The high signals of $\mathrm{m} / \mathrm{z} 44$ were also observed for wood burning OA emissions by Weimer et al. (2008), especially for during the smoldering phase. For $m / z 57$, the signal abundances are similar for cooking and biomass burning emissions, in the range of $0.02-0.06$, but they are significantly lower than those from vehicle exhaust and plastic burning. As $\mathrm{m} / \mathrm{z} 57$ and $\mathrm{m} / \mathrm{z}, 43$ from vehicle exhaust and plastic burning are dominated by hydrocarbon fragments rather than oxygen-containing fragments (Mohr et al., 2009), their higher signals suggest that hydrocarbons are more emitted from vehicles and plastic burning. The fragment at $\mathrm{m} / \mathrm{z}$ $60\left(\mathrm{C}_{2} \mathrm{H}_{4} \mathrm{O}_{2}^{+}\right)$was detected with lower signals for cooking emissions and almost no signals for vehicle exhaust and plastic burning, while it exists with higher signals for biomass burning emissions (0.012-0.057).

The above analysis of the tracer ions in OA UMR-MS from different primary sources may indicate that: (1) the signals at $\mathrm{m} / \mathrm{z} 43$ are less variable among different primary sources; (2) the signals at $\mathrm{m} / \mathrm{z} 44$ from biomass burning emissions are uniquely higher than other primary sources and may interfere the denoting of $\mathrm{m} / \mathrm{z} 44$ for SOA during biomass burning events; (3) $\mathrm{m} / \mathrm{z} 57$ is more characteristic for vehicle hydrocarbon emissions; (4) although $\mathrm{m} / \mathrm{z} 60$ is more significantly emitted from biomass burning, it also exists with detectable signals in cooking emissions.

\section{Conclusions}

Primary emissions from four types of Chinese cooking (CC) and six types of biomass burning (BB) were simulated and measured using an Aerodyne HR-ToF-AMS. All the MS profiles observed are dominated by ions from saturated alkanes, alkenes, as well as possible long-chain fatty acids. The MS of the CC emissions show high similarity, with $\mathrm{m} / \mathrm{z} 41$ and $\mathrm{m} / \mathrm{z} 55$ being the most abundant signals; the MS of the BB emissions also show high similarity, with $\mathrm{m} / \mathrm{z}, 29$ and $\mathrm{m} / \mathrm{z}, 43$ being the most abundant signals. The MS difference between the $\mathrm{CC}$ and $\mathrm{BB}$ emissions is much bigger than that between different CC (or BB) types, especially for HR-MS, therefore cooking and biomass burning emissions are very likely to be separated into two components in MS factor analysis of ambient OA datasets. The $\mathrm{O} / \mathrm{C}$ ratios of $\mathrm{OA}$ range from 0.08 to 0.13 for the $\mathrm{CC}$ emissions and from 0.18 to 0.26 for the $\mathrm{BB}$ emissions. The MS signatures of the $\mathrm{COA}$ and BBOA resolved by PMF analysis of ambient OA datasets in Chinese field campaigns well match those of the $\mathrm{CC}$ and $\mathrm{BB}$ emissions, respectively, strongly supporting their representativeness in the corresponding AMS-PMF studies. HR-MS analysis indicates that the signals of $\mathrm{m} / \mathrm{z} 44$ and $\mathrm{m} / \mathrm{z} 60$ are mostly from $\mathrm{CO}_{2}^{+}$and $\mathrm{C}_{2} \mathrm{H}_{4} \mathrm{O}_{2}^{+}$, respectively, in the $\mathrm{CC}$ and $\mathrm{BB}$ emissions. The signals of $\mathrm{m} / \mathrm{z} 44$ from biomass burning emissions are uniquely higher than other primary sources. The UMR ion of $\mathrm{m} / \mathrm{z}, 60$, typically used as the tracer for biomass burning, also exists significantly in cooking emissions. The MS signatures of cooking and biomass burning emissions revealed in this study will help interpretation of component MS from factor analysis of ambient OA datasets.

\section{Supplementary material related to this article is available online at: http://www.atmos-chem-phys.net/10/11535/2010/ acp-10-11535-2010-supplement.pdf.}

Acknowledgements. This work was supported by the National Natural Science Foundation (20777001) of China, the "863" project (2006AA06A308, 2006AA06A309) from the Ministry of Science and Technology of China, the National Natural Science Funds for Distinguished Young Scholar (21025728), and the Science and Technology Plan Project of Shenzhen Municipality (CXB200903090046A).

Edited by: A. S. H. Prevot 


\section{References}

Aiken, A. C., DeCarlo, P. F., and Jimenez, J. L.: Elemental analysis of organic species with electron ionization high-resolution mass spectrometry, Anal. Chem., 79, 8350-8358, 2007.

Aiken, A. C., Decarlo, P. F., Kroll, J. H., Worsnop, D. R., Huffman, J. A., Docherty, K. S., Ulbrich, I. M., Mohr, C., Kimmel, J. R., Sueper, D., Sun, Y., Zhang, Q., Trimborn, A., Northway, M., Ziemann, P. J., Canagaratna, M. R., Onasch, T. B., Alfarra, M. R., Prevot, A. S., Dommen, J., Duplissy, J., Metzger, A., Baltensperger, U., and Jimenez, J. L.: O/C and OM/OC ratios of primary, secondary, and ambient organic aerosols with high-resolution time-of-flight aerosol mass spectrometry, Environ. Sci. Technol., 42, 4478-4485, 2008.

Aiken, A. C., Salcedo, D., Cubison, M. J., Huffman, J. A., DeCarlo, P. F., Ulbrich, I. M., Docherty, K. S., Sueper, D., Kimmel, J. R., Worsnop, D. R., Trimborn, A., Northway, M., Stone, E. A., Schauer, J. J., Volkamer, R. M., Fortner, E., de Foy, B., Wang, J., Laskin, A., Shutthanandan, V., Zheng, J., Zhang, R., Gaffney, J., Marley, N. A., Paredes-Miranda, G., Arnott, W. P., Molina, L. T., Sosa, G., and Jimenez, J. L.: Mexico City aerosol analysis during MILAGRO using high resolution aerosol mass spectrometry at the urban supersite (T0) - Part 1: Fine particle composition and organic source apportionment, Atmos. Chem. Phys., 9, 66336653, doi:10.5194/acp-9-6633-2009, 2009.

Alfarra, M. R., Prevot, A. S. H., Szidat, S., Sandradewi, J., Weimer, S., Lanz, V. A., Schreiber, D., Mohr, M., and Baltensperger, U.: Identification of the mass spectral signature of organic aerosols from wood burning emissions, Environ. Sci. Technol., 41, 57705777, 2007.

Allan, J. D., Williams, P. I., Morgan, W. T., Martin, C. L., Flynn, M. J., Lee, J., Nemitz, E., Phillips, G. J., Gallagher, M. W., and Coe, H.: Contributions from transport, solid fuel burning and cooking to primary organic aerosols in two UK cities, Atmos. Chem. Phys., 10, 647-668, doi:10.5194/acp-10-647-2010, 2010.

Chirico, R., DeCarlo, P. F., Heringa, M. F., Tritscher, T., Richter, R., Prevot, A. S. H., Dommen, J., Weingartner, E., Wehrle, G., Gysel, M., Laborde, M., and Baltensperger, U.: Impact of aftertreatment devices on primary emissions and secondary organic aerosol formation potential from in-use diesel vehicles: results from smog chamber experiments, Atmos. Chem. Phys. Discuss., 10, 16055-16109, doi:10.5194/acpd-10-16055-2010, 2010.

DeCarlo, P. F., Kimmel, J. R., Trimborn, A., Northway M. J., Jayne, J. T., Aiken, A. C., Gonin, M., Fuhrer, K., Horvath, T., Docherty, K. S., Worsnop, D. R., and Jimenez, J. L.: Field-Deployable, High-Resolution Time-of-Flight Aerosol Mass Spectrometer, Anal. Chem., 78, 8281-8289, 2006.

Docherty, K. S., Stone, E. A., Ulbrich, I. M., DeCarlo, P. F., Snyder, D. C., Schauer, J. J., Peltier, R. E., Weber, R. J., Murphy, S. M., Seinfeld, J. H., Grover, B. D., Eatough, D. J., and Jimenez, J. L.: Apportionment of Primary and Secondary Organic Aerosols in Southern California during the 2005 Study of Organic Aerosols in Riverside (SOAR-1), Environ. Sci. Technol., 42, 7655-7662, 2008.

Drewnick, F., Hings, S. S., DeCarlo, P., Jayne, J. T., Gonin, M., Fuhrer, K., Weimer, S., Jimenez, J. L., Demerjian, K. L., Borrmann, S., and Worsnop, D. R.: A new time-of-flight aerosol mass spectrometer (TOF-AMS) - Instrument description and first field deployment, Aerosol. Sci. Tech., 39, 637-658, 2005.

Gelencsér, A., Hoffer, A., Krivàcsy, Z., Kiss, G., Molnár, A., and Mészáros, E.: On the possible origin of humic matter in fine continental aerosol, J. Geophys. Res.-Atmos., 107, 4137, doi:10.1029/2001JD001299, 2000.

He, L.-Y., Hu, M., Huang, X.-F., Yu, B.-D., Zhang, H.-Y., and Liu, D.-Q.: Measurement of emissions of fine particulate organic matter from Chinese cooking, Atmos. Environ., 38, 6557-6564, 2004.

He, L.-Y., Xue, L., Huang, X.-F., Hu, M., Lin, Y., Liu, R.-L., Zheng, J., Zhang, R., and Zhang, Y.-H.: Submicron aerosol analysis and organic source apportionment in a coastal urban atmosphere in South China using high-resolution aerosol mass spectrometry, J. Geophys. Res.-Atmos., under review, 2010.

Huang, X.-F., He, L.-Y., Hu, M., Canagaratna, M. R., Sun, Y., Zhang, Q., Zhu, T., Xue, L., Zeng, L.-W., Liu, X.-G., Zhang, Y.-H., Jayne, J. T., Ng, N. L., and Worsnop, D. R.: Highly time-resolved chemical characterization of atmospheric submicron particles during 2008 Beijing Olympic Games using an Aerodyne High-Resolution Aerosol Mass Spectrometer, Atmos. Chem. Phys., 10, 8933-8945, doi:10.5194/acp-10-8933-2010, 2010.

Jayne, J. T., Leard, D. C., Zhang, X. F., Davidovits, P., Smith, K. A., Kolb, C. E., and Worsnop, D. R.: Development of an aerosol mass spectrometer for size and composition analysis of submicron particles, Aerosol. Sci. Tech., 33, 49-70, 2000.

Jimenez, J. L., Canagaratna, M. R., Donahue, N. M., Prevot, A. S. H., Zhang, Q., Kroll, J. H., DeCarlo, P. F., Allan, J. D. , Coe, H., Ng, N. L., Aiken, A. C., Docherty, K. S., Ulbrich, I. M., Grieshop, A. P., Robinson, A. L., Duplissy, J., Smith, J. D., Wilson, K. R., Lanz, V. A., Hueglin, C., Sun, Y. L., Tian, J., Laaksonen, A., Raatikainen, T., Rautiainen, J., Vaattovaara, P., Ehn, M., Kulmala, M., Tomlinson, J. M., Collins, D. R., Cubison, M. J., Dunlea, E. J., Huffman, J. A., Onasch, T. B., Alfarra, M. R., Williams, P. I., Bower, K., Kondo, Y., Schneider, J., Drewnick, F., Borrmann, S., Weimer, S., Demerjian, K., Salcedo, D., Cottrell, L., Griffin, R., Takami, A., Miyoshi, T., Hatakeyama, S., Shimono, A., Sun, J. Y., Zhang, Y. M., Dzepina, K., Kimmel, J. R., Sueper, D., Jayne, J. T., Herndon, S. C., Trimborn, A. M., Williams, L. R., Wood, E. C., Middlebrook, A. M., Kolb, C. E., Baltensperger, U., and Worsnop, D. R.: Evolution of organic aerosols in the atmosphere, Science, 326, 1525-1529, 2009.

Jimenez, J. L., Jayne, J. T., Shi, Q., Kolb, C. E., Worsnop, D. R., Yourshaw, I., Seinfeld, J. H., Flagan, R. C., Zhang, X.-F., Smith, K. A., Morris, J. W., and Davidovits, P.: Ambient aerosol sampling using the Aerodyne Aerosol Mass Spectrometer, J. Geophys. Res.-Atmos., 108, 8425, doi:10.1029/2001JD001213, 2003.

Kroll, J. H. and Seinfeld, J. H.: Chemistry of secondary organic aerosol: Formation and evolution of low-volatility organics in the atmosphere, Atmos. Environ., 42, 3593-3624, 2008.

Lanz, V. A., Alfarra, M. R., Baltensperger, U., Buchmann, B., Hueglin, C., and Prévôt, A. S. H.: Source apportionment of submicron organic aerosols at an urban site by factor analytical modelling of aerosol mass spectra, Atmos. Chem. Phys., 7, 1503-1522, doi:10.5194/acp-7-1503-2007, 2007.

Lin, P., Huang, X.-F., He, L.-Y., and Yu, J.-Z.: Abundance and size distribution of HULIS in ambient aerosols at a rural site in South China, J. Aerosol Sci., 41, 74-87, 2010.

Mayol-Bracero, O. L., Guyon, P., Graham, B., Roberts, G., Andreae, M. O., Decesari, S., Facchini, M. C., Fuzzi, S., and Ar- 
taxo, P.: Water-soluble organic compounds in biomass burning aerosols over Amazonia. 2 Apportionment of the chemical composition and importance of the polyacidic fraction, J. Geophys. Res.-Atmos., 107, 8091, doi:10.1029/2001JD000522, 2002.

Miracolo, M. A., Presto, A. A., Lambe, A. T., Hennigan, C. J., Donahue, N. M., Kroll, J. H., Worsnop, D. R., and Robinson, A. L.: Photo-Oxidation of Low-Volatility Organics Found in Motor Vehicle Emissions: Production and Chemical Evolution of Organic Aerosol Mass, Environ. Sci. Technol., 44, 1638-1643, 2010.

Mohr, C., Huffman, J. A., Cubison, M. J., Aiken A. C., Docherty K. S., Kimmel J. R., Ulbrich I. M., Hannigan M., and Jimenez J. L.: Characterization of Primary Organic Aerosol Emissions from Meat Cooking, Trash Burning, and Motor Vehicles with High-Resolution Aerosol Mass Spectrometry and Comparison with Ambient and Chamber Observations, Environ. Sci. Technol., 43, 2443-2449, 2009.

Narukawa, M., Kawamura, K., Takeuchi, N., and Nakajima, T.: Distribution of dicarboxylic acids and carbon isotopic compositions in aerosols from 1997 Indonesian forest fires, Geophys. Res. Lett., 26, 3101-3104, 1999.

Ng, N. L., Canagaratna, M. R., Zhang, Q., Jimenez, J. L., Tian, J., Ulbrich, I. M., Kroll, J. H., Docherty, K. S., Chhabra, P. S., Bahreini, R., Murphy, S. M., Seinfeld, J. H., Hildebrandt, L., Donahue, N. M., DeCarlo, P. F., Lanz, V. A., Prévôt, A. S. H., Dinar, E., Rudich, Y., and Worsnop, D. R.: Organic aerosol components observed in Northern Hemispheric datasets from Aerosol Mass Spectrometry, Atmos. Chem. Phys., 10, 46254641, doi:10.5194/acp-10-4625-2010, 2010.

Novakov, T. and Corrigan, C. E.: Cloud condensation nucleus activity of the organic component of biomass smoke particles, Geophys. Res. Lett., 23, 2141-2144, 1996.

Rogge, W. F., Hildemann, L. M., and Mazurek, M. A.: Sources of fine organic aerosol. 1. Charbroilers and meat cooking operations, Environ. Sci. Technol., 25, 1112-1125, 1991.

Rogge, W. F., Mazurek, M. A., Hildemann, L. M., Cass, G. R., and Simoneit, B. R. T.: Quantification of urban organic aerosols at a molecular level: Identification, abundance and seasonal variation, Atmos. Environ. Part A, 27, 1309-1330, 1993.

Schauer, J. J. and Cass, G. R.: Source apportionment of winter gasphase and particle-phase air pollutants using organic compounds as tracers, Environ. Sci. Technol., 34, 1821-1832, 2000.

Schauer, J. J., Rogge, W. F., Hildemann, L. M., Mazurek M. A., Cass G. R., and Simoneit, B. R. T.: Source apportionment of airborne particulate matter using organic compounds as tracers, Atmos. Environ., 30, 3837-3855, 1996.
Simoneit, B. R. T., Kobayashi, M., Mochida, M., Kawamura, K., Lee, M., Lim, H.-J., Turpin, B. J., and Komazaki, Y.: Composition and major sources of organic compounds of aerosol particulate matter sampled during the ACE-Asia campaign, J. Geophys. Res., 109, D19S10, doi:10.1029/2004JD004598, 2004.

Wang, Q., Shao, M., Zhang, Y., Wei, Y., Hu, M., and Guo, S.: Source apportionment of fine organic aerosols in Beijing, Atmos. Chem. Phys., 9, 8573-8585, doi:10.5194/acp-9-8573-2009, 2009.

Weimer, S., Alfarra, M. R., Schreiber, D., Mohr, M., Prévôt, A. S. H., and Baltensperger, U.: Organic aerosol mass spectral signatures from wood-burning emissions: Influence of burning conditions and wood type, J. Geophys. Res., 113, D10304, doi:10.1029/2007JD009309, 2008.

Zhang, Q., Alfarra, M. R., Worsnop, D. R., Allan, J. D., Coe, H., Canagaratna, M. R., and Jimenez, J. L.: Deconvolution and quantification of hydrocarbon-like and oxygenated organic aerosols based on aerosol mass spectrometry, Environ. Sci. Technol., 39, 4938-4952, 2005.

Zhang, Q., Jimenez, J. L., Canagaratna, M. R., Allan, J. D., Coe, H., Ulbrich, I., Alfarra, M. R., Takami, A., Middlebrook, A. M., Sun, Y. L., Dzepina, K., Dunlea, E., Docherty, K., DeCarlo, P. F., Salcedo, D., Onasch, T., Jayne, J. T., Miyoshi, T., Shimono, A., Hatakeyama, S., Takegawa, N., Kondo, Y., Schneider, J., Drewnick, F., Borrmann, S., Weimer, S., Demerjian, K., Williams, P., Bower, K., Bahreini, R., Cottrell, L., Griffin, R. J., Rautiainen, J., Sun, J. Y., Zhang, Y. M., and Worsnop, D. R.: Ubiquity and dominance of oxygenated species in organic aerosols in anthropogenically-influenced Northern Hemisphere midlatitudes, Geophys. Res. Lett., 34, L13801, doi:10.1029/2007GL029979, 2007.

Zhang, Y. X., Schauer, J. J., Zhang, Y. H., Zeng, L., Wei, Y., Liu, Y., and Shao, M.: Characteristics of Particulate Carbon Emissions from Real-World Chinese Coal Combustion, Environ. Sci. Technol., 42, 5068-5073, 2008.

Zhao, Y. L., Hu, M., Slanina, S., and Zhang, Y. H.: Chemical compositions of fine particulate organic matter emitted from Chinese cooking, Environ. Sci. Technol., 41, 99-105, 2007.

Zheng, M., Hagler, G. S. W., Ke, L., Bergin, M. H., Wang, F., Louie, P. K. K., Salmon, L., Sin, D. W. M., Yu, J. Z., and Schauer, J. J.: Composition and sources of carbonaceous aerosols at three contrasting sites in Hong Kong, J. Geophys. Res., 111, D20313, doi:10.1029/2006JD007074, 2006. 